\title{
Giant Water Bugs, Electric Light Bugs, Lethocerus, Abedus, Belostoma (Insecta: Heteroptera: Belostomatidae) ${ }^{1}$
}

Paul M. Choate ${ }^{2}$

\section{Introduction}

The heteropteran family Belostomatidae contains the giant water bugs. These large, predatory, aquatic insects have the largest body size among the Heteroptera. Adults of some South American species reach 4 inches in length. Individuals occur in ponds and ditches where they suspend below the surface, respiring through two abdominal appendages which act as siphons. During mating season they fly from pond to pond or pool of water. It is during these flights that these insects fly to lights in large numbers, earning their other common name, "electric light bugs". Individuals are capable of inflicting a painful bite with their strong beak, and may also pinch with their front legs. Individuals prey on aquatic insects, small fish, frogs, tadpoles, small birds, and other organisms they are able to capture. Powerful enzymes are injected into prey to kill them. Adults of Lethocerus are considered a delicacy in Asia, and are eaten both fresh and cooked.

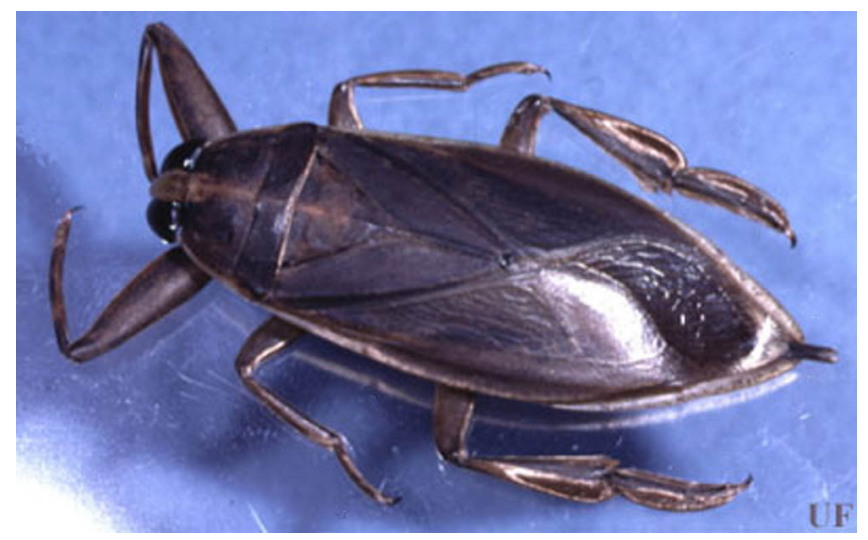

Figure 1. Dorsal view of an adult giant water bug, Lethocerus sp. Credits: P. M. Choate, University of Florida

\section{Life Cycle}

Eggs of Lethocerus are deposited above water on vegetation and other objects. Eggs of Abedus and Belostoma are glued onto males' backs by females. Egg carrying by males is a unique feature in these two genera. Curiously, Kraus (1985) reported that in the absence of sufficient size males, eggs will also be laid on backs of females. Eggs hatch in one to two

1. This document is EENY-301, one of a series of Featured Creatures from the Entomology and Nematology Department, Florida Cooperative Extension Service, Institute of Food and Agricultural Sciences, University of Florida. Published: July 2003. Revised: October 2003. This document is also available on Featured Creatures Website at http://creatures.ifas.ufl.edu. Please visit the EDIS Website at http://edis.ifas.ufl.edu. Additional information on these organisms, including many color photographs, is available at the Entomology and Nematology Department website at http://entnemdept.ifas.ufl.edu/. 2. Paul M. Choate, Department of Entomology and Nematology, Institute of Food and Agricultural Sciences, University of Florida, Gainesville, FL.

The Institute of Food and Agricultural Sciences (IFAS) is an Equal Employment Opportunity - Affirmative Action Employer authorized to provide research, educational information and other services only to individuals and institutions that function without regard to race, creed, color, religion, age, disability, sex, sexual orientation, marital status, national origin, political opinions or affiliations. For information on obtaining other extension publications, contact your county Cooperative Extension Service office. Florida Cooperative Extension Service / Institute of Food and Agricultural Sciences / University of Florida / Larry R. Arrington, Interim Dean 


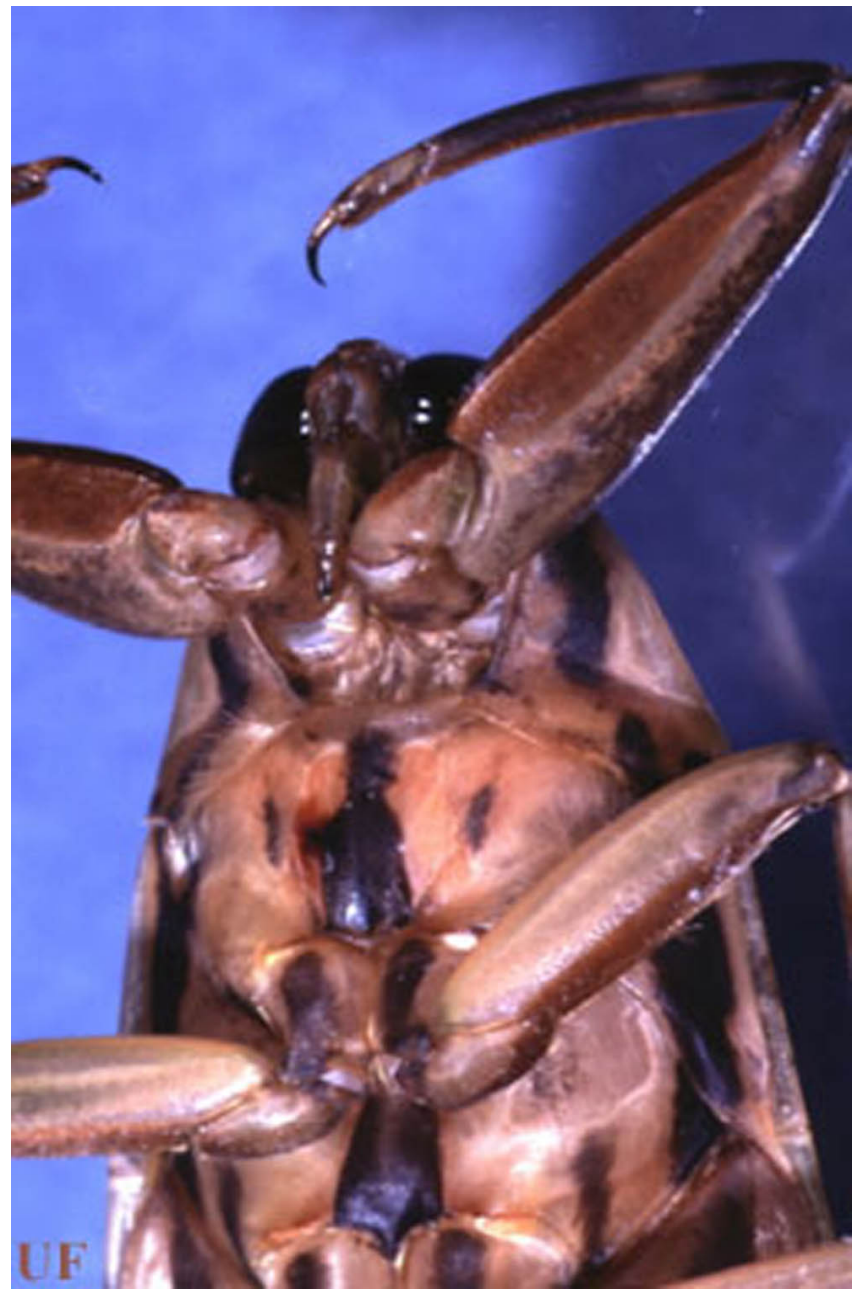

Figure 2. Ventral view of the head of an adult Lethocerus sp., a giant water bug. showing the beak. Credits: P. M. Choate, University of Florida

weeks, with total development time ranging from one to two months. Adults may overwinter in the mud.

\section{Key to Species of Florida Belostomatidae}

Seven genera and approximately 60 species occur worldwide, with three genera and approximately 20 species found in North America. The following three genera containing eight species of Belostomatidae are known to occur in Florida (Henry and Froeschner 1988):

Abedus Stål, 1862

Abedus immaculatus (Say)

Belostoma Latreille, 1807

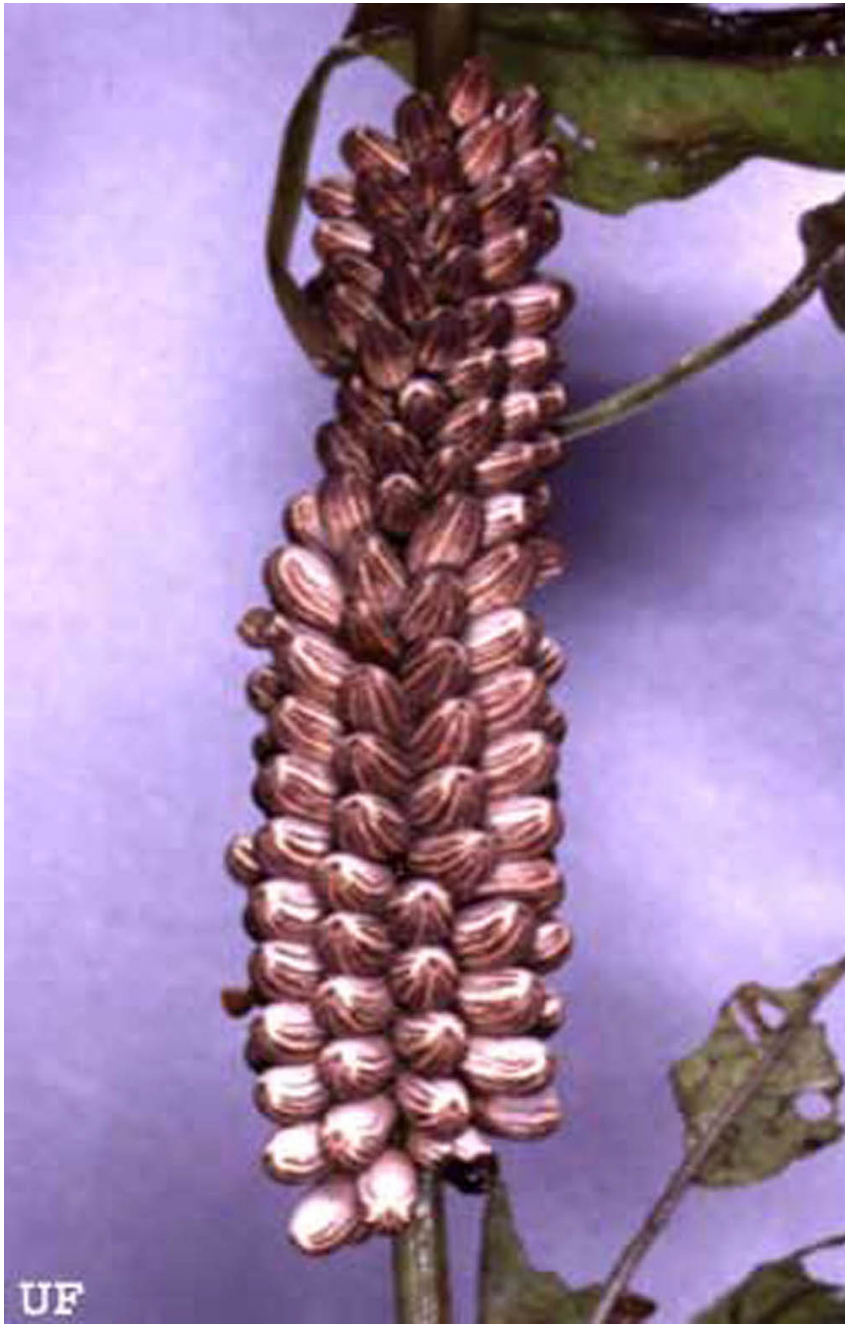

Figure 3. Giant water bug eggs, Lethocerus spp. Credits: Lyle J. Buss, University of Florida
Belostoma flumineum Say
B. lutarium (Stål)
B. testaceum (Leidy)

Lethocerus Mayr, 1853

Lethocerus (Benacus) griseus (Say)

L. (Lethocerus) americanus (Leidy)

L. (L.) annulipes (Mayr) - Palm Beach

L. (L.) uhleri (Montandon)

(species key modified from Bobb 1974, Pennak 1953)

1. Metasternum with a strong midventral keel, membrane of front wing reduced ..... Abedus immaculatus (Say)

1'. Metasternum without midventral keel, membrane of front wing not reduced ..... 2 


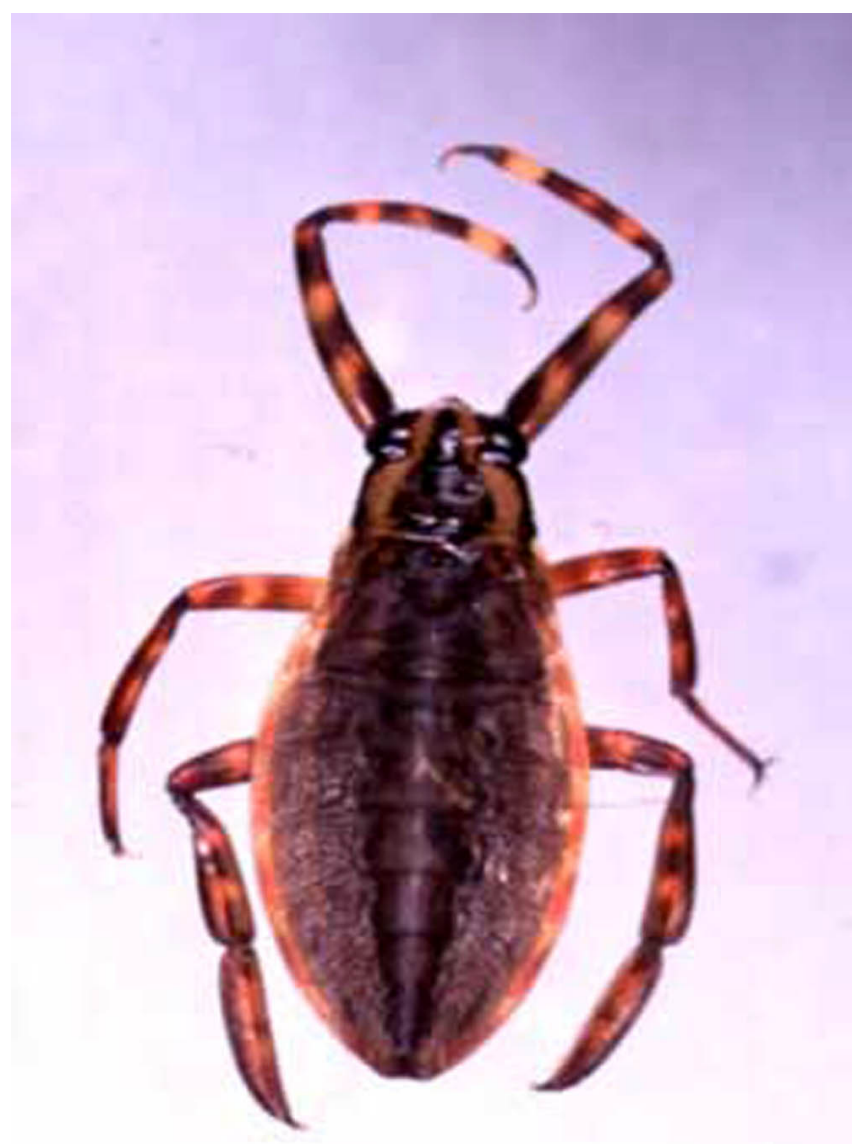

4'. Head as long as middle of pronotum; tylus more convex, very prominent; claval commissure equal to or longer than scutellum; form broadly oval, strongly tapering behind middle of hemelytra . . . . . Belostoma lutarium (Stål)

5. Anterior femur with deep narrow groove for reception of the tibia ....6 6

5'. Anterior femur not grooved for reception of tibia .... Lethocerus (Benacus) griseus (Say)

6. Middle and hind legs not banded, or only faintly so; interocular space equal to width of an eye; costal margins feebly but conspicuously curved .... . Lethocerus americanus (Leidy)

6'. Middle and hind legs distinctly banded; interocular space not over three-fourths width of an eye; costal margin almost straight and subparallel .... ..... Lethocerus uhleri (Montandon)

Figure 4. Giant water bug nymph, Lethocerus spp. Credits: Lyle J. Buss, University of Florida

2. Basal segment of beak longer than the second, less than $30 \mathrm{~mm}$ long..... 3

2'. Basal segment of beak shorter than second, $35 \mathrm{~mm}$ or longer .... . 5

3. Length $20 \mathrm{~mm}$ or greater in length; color dark; head variable; tylus variable .... . 4

3'. Length less than $20 \mathrm{~mm}$; tylus not prominent; color pale brown or testaceous; head only slightly longer than front lobe of pronotum ..... Belostoma testaceum (Leidy)

4. Head slightly longer than frontal lobe of pronotum; tylus less convex, not prominent; claval commissure distinctly shorter than scutellum; form narrow, less tapering behind middle of hemelytra ... . ...... Belostoma flumineum Say

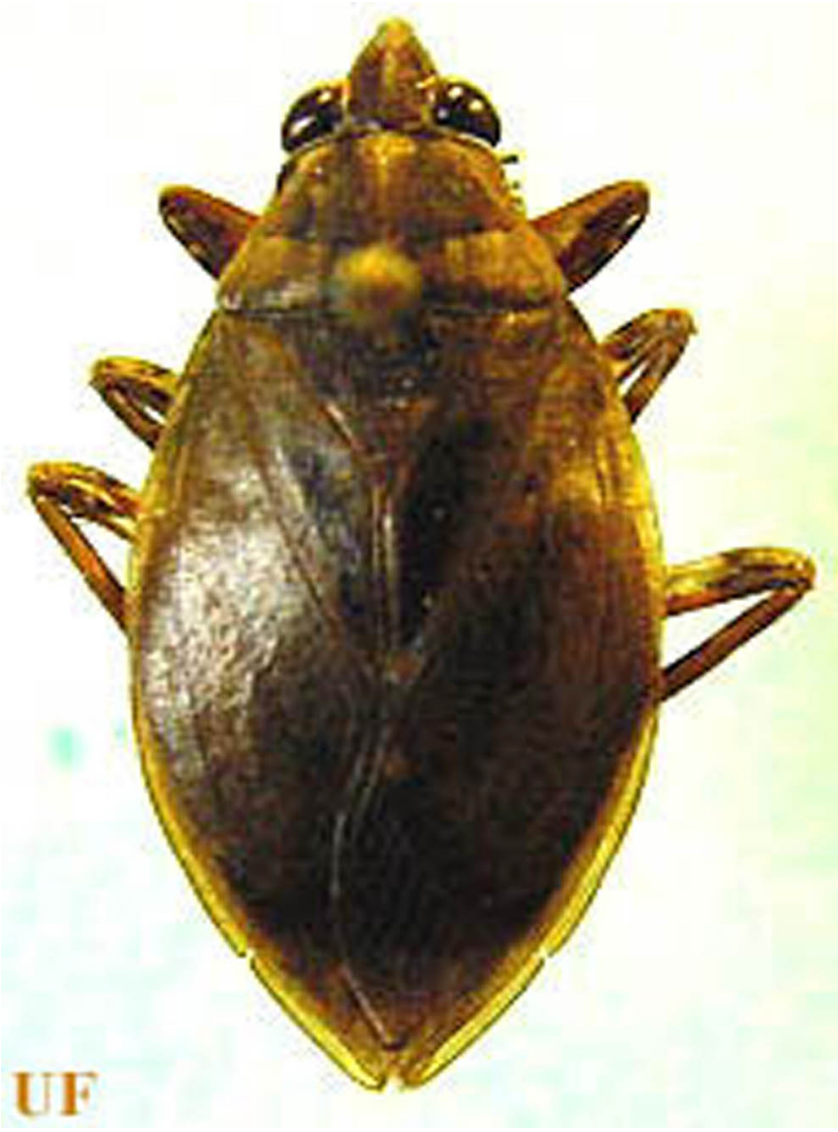

Figure 5. Dorsal view of an adult Abedus lutarium (Stål). Credits: P. M. Choate, University of Florida 


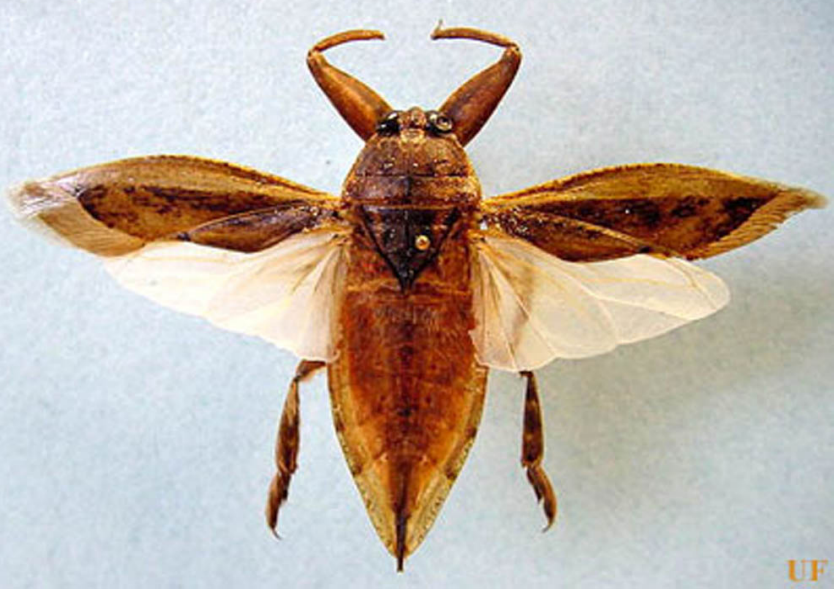

Figure 6. Dorsal view of an adult Lethocerus uhleri (Montandon). Credits: P. M. Choate, University of Florida

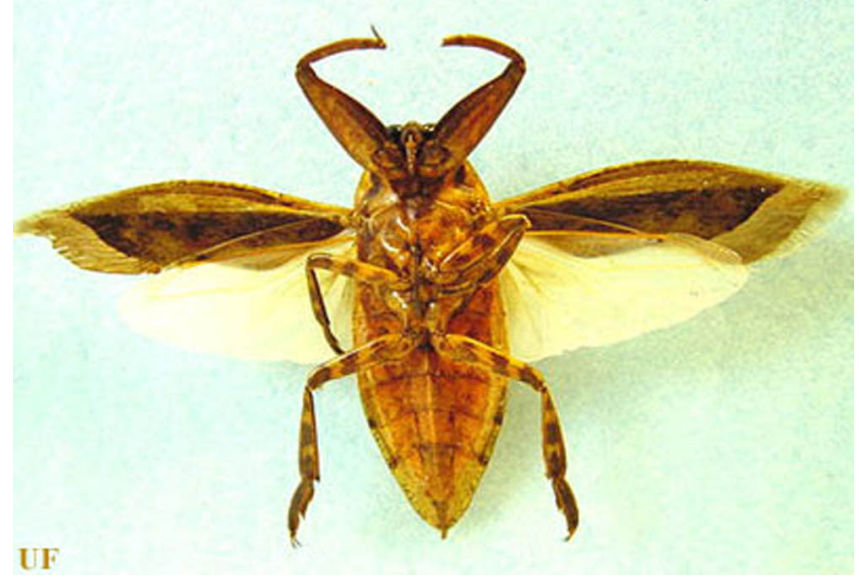

Figure 7. Ventral view of an adult Lethocerus uhleri (Montandon). (Note banded middle and hind legs). Credits: P. M. Choate, University of Florida

\section{Distribution}

Abedus immaculatus (Say) - Florida, Georgia, and Mississippi;

Belostoma flumineum Say - Quebec and New England, west to Manitoba and Colorado, southwest to Florida, Louisiana, and Arizona;

Belostoma lutarium (Stål) - Massachusetts southwest to Louisiana and Texas; Kansas;

Belstoma testaceum (Leidy) - New York west to Michigan and southwest to Florida and Texas;

Lethocerus griseus (Say) - Massachusetts west to Michigan; south to Florida and Texas; Mexico to Guatemala, West Indies;
Lethocerus uhleri (Montandon) Massachusetts, west to Ontario, south to Texas; Mexico;

Lethocerus annulipes (Herrich-Schaeffer) Florida? South America, West Indies; reported from Palm Beach, Florida.

Lethocerus americanus (Leidy) -

Newfoundland, Maine to British Columbia, south to Utah and Nevada, Mexico, Florida?

\section{Selected References}

Blatchley WS. 1926. Heteroptera of Eastern North America with especial reference to the faunas of Indiana and Florida. Nature Publishing Company, Indianapolis, Indiana. 1116p.

Bobb ML. 1974. The Insects of Virginia: No. 7. The aquatic and semi-aquatic Hemiptera of Virginia. Research Division Bulletin 87. Virginia Polytechnic Institute and State University, Blacksburg, Virginia. $196 \mathrm{p}$.

Dubois RB, Rackouski ML . 1992. Seasonal drift of Lethocerus americanus (Hemiptera:

Belostomatidae) in a Lake Superior tributary. Great Lakes Entomologist 25: 85-89.

Flosi JW, Hart ER. 1987. Endocuticular growth rings as an indicator of age structure in Belostoma flumineum Say (Hemiptera: Belostomatidae). Iowa State Journal of Research 62: 189- 198.

Henry TJ, Froeschner RC (eds.). 1988. Catalog of the Heteroptera, or True Bugs, of Canada and the Continental United States. E. J. Brill, New York. 958p.

Hungerford HB. 1920. The Biology and Ecology of Aquatic and Semiaquatic Hemiptera. Kansas University Science Bulletin XI: 1-256.

Hussey RF, Herring JL. 1950a. A remarkable new Belostomatidae (Hemiptera) from Florida and Georgia. Florida Entomologist 33: 84-89.

Hussey RF, Herring JL. 1950b. Rediscovery of a Belostomatidae named by Thomas Say (Hemiptera). Florida Entomologist 33: 154-156. 
Ichikawa N. 1988. Male brooding behavior of the giant water bug Lethocerus deyrollei Vuillefroy (Hemiptera: Belostomatidae). Journal of Ethology 6: 121-128.

Ichikawa N. 1989. Breeding strategy of the male brooding water bug, Diplonychus major Esaki (Heteroptera: Belostomatidae): Is male back space limiting? Journal of Ethology 7: 133-140.

Ichikawa N. 1995. Male counterstrategy against infanticide of the female giant water bug Lethocerus deyrollei (Hemiptera: Belostomatidae). Journal of Insect Behavior 8: 181-188.

Keffer SL, McPherson JE. 1988. Descriptions of nymphal instars of Abedus breviceps (Hemiptera: Belostomatidae). Great Lakes Entomologist 21: 169-174.

Kehr AI, Schnack JA. 1991. Predator-prey relationship between giant water bugs (Belostoma oxyurum) and larval anurans (Bufo arenarum). Alytes 9: 61-69.

Kight SL, Sprague J, Kruse KC, Johnson L. 1995. Are egg-bearing male water bugs Belostoma flumineum Say (Hemiptera: Belostomatidae), impaired swimmers? Journal of the Kansas Entomological Society 68: 468-470.

Kraus B. 1985. Oviposition on the backs of female Giant water bugs, Abedus indentatus: the consequences of a shortage in male back space? (Hemiptera: Belostomatidae) Pan-Pacific Entomologist 61: 54-57.

Kraus WF. 1989. Surface wave communication during courtship in the giant water bug, Abedus indentatus (Heteroptera: Belostomatidae). Journal of the Kansas Entomological Society 62: 316- 328.

Kraus WF, Gonzales MJ, Vehrencamp SL. 1989. Egg development and an evaluation of some of the costs and benefits for paternal care in the Belostomatidae, Abedus indentatus (Heteroptera: Belostomatidae). Journal of the Kansas Entomological Society 62: 548-562.

Kruse KC, Leffler TR. 1984. Females of the giant water bug, Belostoma flumineum (Hemiptera:
Heteroptera: Belostomatidae), captured carrying eggs. Annals of the Entomological Society of America 77: 20.

Lauck DR, Menke AS. 1961. The higher classification of the Belostomatidae (Hemiptera). Annals of the Entomological Society of America 54: 644-657.

Leidy J. 1847. History and anatomy of the Hemipterous genus Belostoma. Journal of the Academy of Natural Sciences of Philadelphia (2) I:57-57.

McPherson JE, Packauskas RJ. 1986. Life history and laboratory rearing of Belostoma lutarium (Heteroptera: Belostomatidae) with descriptions of immature stages. Journal of the New York Entomological Society 94: 154-162.

Menke AS. 1960. A taxonomic study of the genus Abedus Stal (Hemiptera: Belostomatidae). Univ. California Publications Entomology 16: 393-439.

Needham JG. 1907. The eggs of Benacus and their hatching. Entomological News 18: 113-116. Pennak, R. W. 1953. Fresh-water Invertebrates of the United States. Ronald Press Company, New York. 769 p.

Smith RL, Larsen E. 1993. Egg attendance and brooding by males of the giant water bug Lethocerus medius (Guerin) in the field (Heteroptera: Belostomatidae). Journal of Insect Behavior 6: 93-106.

Smith RL. 1979. Paternity assurance and altered roles in the mating behavior of a giant water bug, Abedus herberti (Heteroptera: Belostomatidae). Animal Behaviour 27: 716-725.

Smith RL, Horton C. 1998. Fish predation on giant water bug (Heteroptera: Belostomatidae) eggs in an Arizona stream. Great Basin Naturalist. 58: 292-293.

Venkatesan P, D'Sylva T. 1990. Influence of prey size on choice by the water bug, Diplonychus indicus Venk. and Rao (Hemiptera: Belostomatidae). Journal of Entomological Research 14: 130-138. 
Venkatesan P. 1983. Male brooding behavior of Diplonychus indicus (Hemiptera: Heteroptera:

Belostomatidae). Journal of the Kansas

Entomological Society 56: 80-87.

Wilcox RS. 1995. Ripple communication in aquatic and semiaquatic insects. Ecoscience 2:

109-115. 